\title{
Teaching Practice Representations in Higher Education from the Perspective of Students: Contributions for Professor Training1
}

\author{
Gildo Volpato, Angela Cristina Di Palma Back \\ Humanities, Science and Education Department, Universidade do Extremo Sul Catarinense (UNESC), Criciúma, Brasil \\ Email:acb@unesc.net
}

How to cite this paper: Volpato, G., \& Di Palma Back, A. C. (2016). Teaching Practice Representations in Higher Education from the Perspective of Students: Contributions for Professor Training. Creative Education, 7, 2305-2329.

http://dx.doi.org/10.4236/ce.2016.715224

Received: August 29, 2016

Accepted: September 24, 2016

Published: September 27, 2016

Copyright $\odot 2016$ by authors and Scientific Research Publishing Inc. This work is licensed under the Creative Commons Attribution International License (CC BY 4.0).

http://creativecommons.org/licenses/by/4.0/

\section{Abstract}

This article discusses the representations of higher education teaching practice according to the students' perspective. The sample comprised 393 students and 14 professors of three universities of Santa Catarina State in Brazil that traditionally conferred degrees upon professionals of Law, Civil Engineering and Medicine. Among the theorists brought into the discussion, we can mention Berstein (1990), Bourdieu (1983, 1990), Chauí (2001), and Tardif (2002). Then we present the obtained results by mapping the students' parameters and value judgments of their positive assessment of professors and teaching practice in order to contribute to future discussion in terms of professors' training.

\section{Keywords}

Professor's Training, Teaching Practice Representations, Teaching and Learning, Higher Education, Higher Education Professor

\section{Introduction}

Some time ago the established images for university teaching and for their students could be summarized as, on one side, those that lectured about a certain theoretical subject and demonstrated in practice some professional procedures and, on the other side, those who aimed at graduating with technical competence to practice a profession in the labor market, and getting qualifications in order to reach a certain professional stability.

${ }^{1}$ It is an unpublished study that correlates knowledge from research studies from "LITTERA-Correlations between culture, processing and teaching: language in focus" and "Practices, knowledge and professor training", linked to the research lines of the Master's Program in Education "Education, Language and Memory" and "Training and Management in Educational Processes". The financing source is Programa pro-stricto whose budget provides support for professors' researches of the Graduate Program in Education. 
In this context the choice of a professor is based on the belief that the one who knows how to do well, most certainly knows how to teach well. For a long time with this established representation, highly sought professionals to teach at the university were identified as those who were the most successful in their activities in a field that corresponded specifically to the college in which they would teach.

Since the last two decades, this linear relationship between professional performance and teaching profile at higher education has been changing, especially due to the increasing discussion and debate about the social role of the university and the need of professionalizing teaching at higher education. These are new needs and challenges that modern society presents to the university so that it demands a new teaching profile especially due to the power of Lei de Diretrizes e Bases da Educação Nacional-LDB 9394/96 (Brazilian Law of Guidelines and Bases of National Education).

As a demand, LDB universities had to comply with having $1 / 3$ of professors with Doctoral and Masters Degrees as well as having a total of $1 / 3$ of their faculty members working full-time.

It is important to stand out that the demand for degrees is only signaling the need to excel at competences that must be ensured to the professor once there are others that must be set to reach the desired quality in higher education. The same way the requirement for full-time is a consequence of the worry that the professor, besides teaching, performs other activities as research and extension. Also the need for qualification for teaching at higher education is a premise of the new LDB.

This way the university becomes the place where professors of several professional areas cross, promoting their selection and continuing education. These professionals of different knowledge areas bring the marks of their education, mainly of the period of academic and professional education in which many constitutive elements of the professional identity were structured, shaped, and constituted themselves.

Among the constitutive elements of setting the identity are the concepts of professional regulation, code of ethics, social acknowledgement, economic return and personal satisfaction. These are the representations about the profession that the students, future professionals, are also constructing.

Paradoxically the process that takes the same professional to teach at higher education does not occur the same way once there is no time for instruction and reflection about the new profession they are going to start.

After some time of teaching some professionals that start working at higher education, even without a formal pedagogical instruction, strengthen their position as their students assess them positively. Most times they head for teaching in an incidental way and, even so, some of them become a reference, and are considered as good professors by their students, in a way that is a process and condition of teaching practice.

To investigate this state of affairs, we accomplished a research based on the presupposition that it was fundamental to know and understand these subjects, and professionals of different areas of knowledge had also chosen higher education teaching as a professional activity. 
The research was accomplished at three universities comprising three undergraduate colleges that traditionally confer degrees upon professionals: Law, Civil Engineering, and Medicine. The subjects of the research added 393 graduating students that replied the questionnaire (Appendix A) in the three colleges, at the three higher education institutions, and 14 professors with professional education corresponding to the colleges in which they taught and that were indicated by the students as a reference in teaching practice.

In short, this article aims to present the results on the representations of the students about professionals' teaching practice considered as a reference in higher education. This way, questions related to the research are: who are the professors, reference in teaching practice, in the undergraduate degrees of Law, Civil Engineering, and Medicine? Why are they considered as reference in teaching practice by graduating students? What elements of their practices and attitudes are pointed out as reference?

The presented results make part of a sample data of a research accomplished for the doctoral dissertation of Volpato (2007), focusing on the colleges already mentioned that, according to Enguita's (1991) classification, confer a degree upon professionals. The three universities are from Santa Catarina State in Brazil and are affiliated to the Associação Catarinense das Fundações Educacionais (ACAFE (Santa Catarina State Association of Educational Foundations)), namely, Universidade do Extremo Sul Catarinense, UNESC-Criciúma campus; Universidade do Sul de Santa Catarina, UNISUL-Tubarão campus; Universidade do Vale do Itajaí, UNIVALI-Itajaí campus².

This study is organized into sections and aims to explain the students' and professors' representations about the professors and the higher education teaching practice. The second section presents theoretical discussions on representations at and by universities about teaching spaces and consequently about teaching culture of the different areas of knowledge researched with the respective values that these areas individually create due to their identities. On the third section we review the obtained results concerning the parameter mapping and value judgments used by the students while they positively assessed professors and teaching expecting to contribute for future discussions in terms of training of higher education professors. Finally we conclude with some considerations about the teaching profile that we should seek in order to balance what kinds of students' value and what colleges and universities are expected to reach the quality standards in higher education.

\section{Representations-Literature Review}

\subsection{University: Space of Contradictions}

In the constitution of universities historical context there was an increasing social demand for higher education and the university based on the classical professional colleges was not able to fulfill the new requirements of the national project implanted by the military regime. As a consequence a new identity for the university started to be defined during the second half of the 1960's as the appropriate institution for higher edu-

\footnotetext{
${ }^{2}$ There is a table in Appendix B in which the parameters concerning the sample are systematized.
} 
cation, so a college not linked to a university would be admitted only under exceptional circumstances.

At universities teaching would be inseparable of research that would preferably be developed in graduate programs. The cathedra system was extinguished and in its place departments were established. The Law 5.539/68 modified the Teaching Statute of Federal Institutions of Higher Education. Advancement in the teaching career has considered the academic degrees of Master and Doctor as well as it included the full-time system, which has been stimulated as it aimed to retain research professors in the federal public institutions.

The termination of the cathedra system in 1968 favored the emergence of master's and doctoral programs. According to Cunha (1998), research and graduate programs, stimulated by the allocation of resources for this end and without the interference of university presidencies, promoted the formation of a new identity for the Brazilian university.

Identity formation of the modern university presents multiple functions so that, at first, it can be questioned if it is possible and compatible to develop all of them in one institution without facing shock, clash, and contradiction. For Sousa Santos (1999), contradiction is one of the characteristics that chiefly marks universities nowadays. In the investigation domain the scientific interest can be a lot different from the interest of strengthening the economic competitiveness. In teaching goals of general education and cultural preparation can collide, within the same institution, with professional education and specialized education.

Based on Chauí (2001) we can trace the historical path that characterizes the university identity at each synchronic cut. Let's see:

University - identity characterization
Classical $\begin{aligned} & \text { Functional }{ }^{3} \\ & \text { focused on knowledge focused on labor market focused on company interests focused on itself as a management structure }\end{aligned}$
according to her "it was a consolation prize that dictatorship offered to its ideological and political suppor-
ters, that is, to the middle class deprived of power" and to whom was promised prestige and upward social
mobility by means of a university diploma.
'For the period of 1980's, Chaú (2001) characterizes the university of results by the increasing expansion of
private schools in higher education that were responsible to continue to foster the middle class social dreams
and by the introduction of the idea of partnership between public universities and private companies. This
aspect was decisive once companies should not only ensure jobs for future professionals and pay internship
for students as they should also fund researches related to their interests As the author says, "employment
and research immediate usefulness guaranteed universities to present themselves as institutions that deliver
results" (p. 190).
'In line with the discourse of modernization that guided the political project of the first government endorsed
at the polls after the military regime, it would be responsibility of higher education institutions the education
of human resources demanded by an increasingly competitive market. This market was developing from the
desire of inserting Brazil in the First World, articulated with international organizations. This period of uni-
versity performance characteristic of the 1990's Chaú (2001) named operational university.


These different periods in which the institutional identities were established with clearly defined purposes make up the current scenario of the university. In a certain way, during the functional period when undergraduate courses were indiscriminately offered and the preoccupation with professionals' fast graduation required as highly qualified workforce for the labor market is a situation that still persists. According to Chauí (2001), in order to adapt themselves to the demands of the market, the university changed curricula, programs and activities in order to ensure the students' professional insertion in the labor market. This as well as the other periods helped and help to construct the identity of the university today assuring space for contradictions at the heart of the academic community as Sousa Santos (1999) set forth.

Dias Sobrinho (2005: p. 33) reinforces this position stating that contradiction is a constituent element of the university. According to him, "como tudo o que é social, a educação superior vive e produz grandes contradições. A cada tempo e em cada lugar vive as tensões da sociedade e responde a muitas de suas demandas, ora com mais, ora com menos autonomia, porém jamais imune às contradições (as everything that is social, higher education lives and produces great contradictions. Each time and at each place it lives the tensions of society and responds to many of its demands sometimes with more autonomy and other times with less, however it is never free from contradictions)".

\subsection{Higher Education Teaching: Representations about Teaching Space}

In the space of contradictions representations about several social actors are constructed and, among them, the teacher to which we survey how to be and how to do in higher education.

LDB in its Article 66 states that the preparation to higher education teaching practice will be accomplished at graduate levels, priority given to master's and doctoral programs. In this sense the Law asserts, as Cury (2006: p. 275) puts forth, "que o exercício do magistério superior não é um campo para diletantes, voluntários, amadores ou mesmo pessoas mal preparadas. A docência é um campo profissional e o exercício do magistério conta, de longa data, com um saber que lhe é próprio (that higher education teaching practice is not a field for dilettantes, volunteers, amateurs or ill-prepared people. Teaching is a professional area and the teaching practice for a long time has had a knowledge of its own)".

The image constructed by Masetto (1998: p. 13) corroborates Cury's statement when stressing that nowadays "a docência no ensino superior exige não apenas domínio de conhecimentos a serem transmitidos por um professor como também um profissionalismo semelhante àquele exigido para o exercício de qualquer profissão. A docência nas universidades e faculdades isoladas precisa ser encarada de forma profissional, e não amadoristicamente (higher education teaching demands not only mastery of knowledge to be delivered by a professor, but also professionalism required for the practice of any profession. Teaching at universities and a college not linked to a university needs to be faced in a professional and not in an amateur way)". In other words Masetto (1998: p. 
11) reasserts that "o exercício docente no ensino superior exige competências específicas, e não se restringe a ter um diploma de bacharel, ou mesmo de mestre ou doutor, ou, ainda, apenas o exercício de uma profissão. Exige isso tudo, além de outras competências próprias (higher education teaching practice demands specific competences and is not restricted to the fact of having a bachelor's diploma or even a master's or doctoral degree, moreover it is not only the practice of a profession. It claims all this besides other specific competences)".

Vasconcelos (2000) stresses the importance of the professor's social role when she points out that the needed qualification for the higher education teaching practice must cover all different aspects of professional competence: technical and scientific education (professors should have in-depth technical knowledge of the content to be taught and of the essential concepts of the course in which they work); practical experience (that can only be evident from the professional practice knowledge, from the experiences in the field in which they are licensed); political knowledge (education as an intentional political act demands ethics and commitment to a conception of man, society and world); and pedagogical training (the daily process of constructing the pedagogical activity in classroom, forms of action, and adopted methodologies).

It is possible to summarize the competences assigned to the professor with the aid of Masetto (1998) that presents some requisites for a professional to practice with competence higher education teaching.

1) Higher education teaching demands mastery in the knowledge area.

This means mastering basic knowledge of a determined area as well as professional field experience. This knowledge is generally acquired in undergraduate programs and through the exercise of the profession with social practice. It is also expected that a professor constantly updates knowledge and professional practices with refresher courses, specializations, congresses, symposia, exchange programs etc.

It is also expected that a professor can do research at several levels since the production of papers of studies and critical reflections about theoretical aspects or personal experiences to be discussed with students up to the production of new scientific knowledge or cutting-edge technology accomplished as a result of research projects that involved resources and support of funding sources.

2) Higher education teaching requires knowledge in the pedagogical area.

The author presents four aspects that he considers fundamental to act with professionalism in higher education teaching: i) the concept of teaching and learning process; ii) the professor as the curriculum designer and manager; iii) professor-student and student-student relationship in the process; iv) educational technology theory and practice. In terms of the concept of teaching and learning process the author emphasizes that the major goal of teaching is the students' learning.

3) Teaching in higher education demands the practice of the political dimension.

Every pedagogical action implies a political stance, decision-making, defense of ideas, and postures coherent with them in the professional and personal life.

Nóvoa (1992) observes that it is necessary to think about three aspects that support 
the professor's identity: $A$ dherence to principles and values; $A$ ction, it is necessary to know how to choose teaching methods and techniques as success or failure of certain experiences mark the pedagogical posture and makes us feel good or bad with this or that way of working; and Self-Awareness, considering that everything is decided during the professor's reflection process about his or her own action.

Even if the definition of a good professor is essentially subjective, some characteristics are fundamental for the quality of teaching practice. Under this perspective, some researchers mention the issue of teaching knowledge, explaining that "o saber representa o fundamento da competência técnico-científica para o desenvolvimento de sua ação e se relaciona às dimensões ética, política, social e cultural (knowledge represents the basis of technical and scientific competence for the development of the action and is related to ethical, political, social and cultural dimensions)".

It is interesting to highlight, in terms of competences, that there can be contradictions in the field of representations that several actors have of themselves and of the other in the context of teaching and learning. Therefore defining how an ideal professor would be is always a complex task and many times contradictory. This is so because such a definition necessarily implies attributing subjective elements. This means that a student can consider a professor as excellent while another one does not see him or her the same way. So the representation the students have of a good professor involves the subjective character of a value judgment.

Cunha (1989) considers the good professor concept evaluative as it is related to a time and a place and has an ideological character to the extent to which it represents the socially constructed idea about the professor and the attributes that would characterize the ideal professor. It is also important to emphasize that the elements that represent the vision professors have of their teaching practice does not always match the vision the students have of their performance and this should also be considered when professors and students are evaluated. For this reason continuing education projects of teaching professionalization should turn down the idea of theoretical discussions that are disconnected from practical contexts and from the participants' needs. If it is so, it is possible to point out unfoldings that go beyond knowledge and that necessarily pervade the know how to do.

After these considerations we review positionings about how the professor produces and conducts knowledge in the classroom space.

\subsection{Higher Education Teaching Practice: Teaching Culture in Action}

Tardif (2002) presents an important questioning about which we should think about: teachers are only "transmitters" of knowledge produced by other groups? Or do they produce knowledge in their professional area?

Historically there has been a separation between two complementary phenomena: the processes of social knowledge production, which were and still are carried out by researchers of education and of scientific communities of different knowledge areas, and the social processes of knowledge formation and transmission, which are under the 
responsibility of educators, in other words, professors.

Knowledge of professional training, course and curriculum design, that the professor have and transmit are not the professors' knowledge as they do not participate of its construction and generally they are not defined by them. In higher education if they do not participate of research groups they are subject to follow ready-made syllabi, and in elementary and middle school education to the National Curricular Parameters and to Town or State Curricular Proposals or to textbooks where the content is previously prepared and the methodology is already defined. Therefore teachers develop a relationship of exteriority. A social, institutional and epistemological distance separates and deprives them of the knowledge produced, controlled and legitimated by others.

Under this perspective most knowledge with which teachers work are not produced or elaborated by them and this results in overestimating knowledge that advances from practice. Experience-based knowledge according to Tardif (2002) consists of a set of representations from which teachers interpret, understand and lead their professions and daily practice in all its dimensions. They provide certainty regarding the working space within the school. It constitutes the teaching culture in action.

This way teachers end up conferring a special status to experience-based knowledge and this becomes the bases of practice and of professional competence. For Tardif (op. cit.), from experience-based knowledge teachers try to change the relationship of exteriority of knowledge into relationship of interiority of their own practice. Due to this situation, Tardif (2000: p. 11) calls as epistemology of professional practice the set of knowledges used by professionals in their daily working space to perform all their tasks. It is "saberes do trabalho, saberes no trabalho (knowledge of work, knowledge in the workplace)". When the author expresses himself this way, he calls the attention to the fact that professional knowledge is knowledge worked out, incorporated in the teaching practice process, which only make sense in terms of work situations. It is in these situations that knowledge is constructed, shaped and used in a significant way by workers.

On the other hand, in the context of contradictions of higher education institutions, the image of teaching-as-job is opposed to teaching-as-research. Professors that work and that are also researchers participate of research groups and seek, according to Bourdieu (1983), "a definição de ciência que se conforma melhor a seus interesses específicos, isto é, a que lhes convém melhor e lhes permite ocupar, em toda legitimidade, a posição dominante (the definition of science that best corresponds to their specific interests, that is, that suits them best and allows them to legitimately occupy the dominant position)" (p. 21). Therefore there is in each social field a continuous struggle for the monopoly of scientific competence (through symbolic capital of the work regarding publication of scientific knowledge or as a symbolic producer of science). The scientific field, as Bourdieu (1983) states, seen as a system of objective relations between positions obtained in previous struggles, is the place, the space of the play of competitive struggles. What is at stake is the monopoly of scientific authority in terms of the technical capacity as well as of the social power that it represents, or, as the monopoly of scientific competence that is understood as the ability to legitimately 
speak and act (that is, in an authorized way and with authority) that is socially granted to a particular agent.

What a professor that is a researcher perceives as important and interesting tends to have the best opportunities to be recognized as important and interesting by other professor who are researchers. In this sense the theme, the subject and the discovery that has the best chance of yielding the highest symbolic profit becomes the most important research object.

Bourdieu (1983) reminds us that the higher education space, as the place where science is produced, is a social field as any other and as such is subject to establishing relationships of power and monopoly, with struggles and strategies to reach interests and profits.

Based on the concepts presented by Bourdieu and also supported by Bernstein and Enguita's concepts, Cunha and Leite (1996) made evident, in their research accomplished at two universities in the Brazilian state of Rio Grande do Sul, that in any university the values that are present in the scientific community of the courses of the so called professions are relatively constant. The authors state that generally professional performance is highly valued regarding clients' social position, cases of success, office location, participation in congresses that are published in newspapers etc, besides students' acknowledgement as a good professor, because all this also constructs reputation. In this sense teaching is valued by what it represents in terms of recognition as the professor's image of success is valued through professional success because it furthers his or her performance in the professional field especially when former students make public his or her qualities.

Consistent with this position, professors who are professionals are not always worried about attending a graduate course as these courses do not give public recognition. Cunha and Leite (1996) also explain that as they have the power and voice linked to learning as the transmission of knowledge, difficulties for changes are also created.

Consequently in each knowledge area, in each program of these areas, it is perceived as a basic value the recognition from the peers' that are formed in the academic space as well as within the wider scientific community. However values can be different depending on the history of each field, commitments, practices of each group, and professional area in which it is inserted. It was also possible to observe, as Cunha and Leite (1996) state, that professionals from several areas introduce values and practices inherent to their professional fields, reproducing, in the decisions of teaching practice, the mechanisms of knowledge control characteristic of their cultural capital and their scientific competence.

When Cunha (2004) explains that the professional condition of the professor is inscribed in a multiplicity of factors of historical and cultural nature, she points out that it is not separately defined and that it does not depend exclusively of technical typologies, but it is a minefield of contradicting and mutually dependent energies. This way autonomy and authority, attributes many times required from and needed by professors to develop their work in the classroom space, are not only individual attributes, but are 
inscribed in a net of influences that reach the professional collectivity, constructing a culture. "A prática pedagógica pode ser entendida como um dispositivo transmissor, um transmissor cultural. Um dispositivo unicamente humano, tanto para a reprodução como para a produção da cultura (The pedagogical practice can be understood as a transmitter, a cultural transmitter. It is a solely human device for the transmission as well as for the production of culture)" (Bernstein, 1990: p. 68).

What has been presented has contextualized the explicit and hidden rules that condition teaching behavior, modeling its particular way of constructing communication in each classroom and in each educational institution. Perez Gomes (2001) explains that the teaching culture is conditioned by the historical experiences accumulated in the performance patterns of the social group, but it is also a consequence of external forces and expectations, of demands of socialization processes and of situational demands of the other involved agents. The teaching culture is specified through methods used in classroom, quality concepts, direction and guidance of interpersonal relations, professors' roles and functions definition, including management methods, participation structures and decision-making processes.

Generally professors teach and evaluate their students based on the way in which they were taught and evaluated, based on the representations formed throughout their personal and professional history. This way they ensure practices that are more or less efficient in terms of knowledge and of evaluations that are identical to the ones they themselves were subject to. This perspective confirms teaching as habitus as Kessler (2002) pointed out. It is observed that in education the ways of control and power or of regulation become materialized through pedagogical practice, or better, through pedagogical practices.

Based on the above it is understood that habitus is not necessarily something unchangeable as professors still have spaces to move, to relate themselves in the university to a larger world than the one that defines the specific knowledge of their subject. The contradiction is established in the spaces characterized by human actions and intentions. In this sense even if it is possible to identify the strong presence of reproduction and of regulatory processes arising from policies and traditional practices, professors, as Bourdieu (1996) states, consciously or not, maybe for practical reasons, many times resist to become only the object of the action they develop. It is possible to resist and resisting also implies power.

\section{Representaions-Constituted Spaces}

Based on what was presented about teaching representations, we start the discussions about the results of the research. The first one refers to the representations of professors and teaching practice according to the students' perspective, considering the reasons for choosing a professor as a reference in teaching practice, which necessarily takes to certain representations. Besides this the discussion about the results we end by correlating them to data gathered in Argentina, which show strong cultural components produced in the knowledge areas studied, once in both spaces the results are similar. 


\subsection{Representations of Professors and of Teaching Practice: Students' Perspective}

The student's assessment of the professor does not occur in an isolated neutral way, but in a space of contradictions where meanings are attributed in and by the collective, so that the representations so constituted are shared by the members of the same social group (in this case the students) in a general way and, at the same time, in a particular way as they belong to three programs of specific areas of knowledge. Considering precisely this power game between general and particular aspects, the presentation of the results of the research was organized.

According to Guidi (2001), in all human phenomena that is integrated to the structure of the personality there are processes of a "profunda e solidária inter-relação (deep and supportive interrelationship)" (p. 21). The representation is not simply a reproduction or reflection of the outside world, but a construction with some autonomy, individual and collective creation. The representations play a role in society so that, according to Bourdieu (1983), they get to condition the subjects' thoughts and actions. In other words, life in society is a space where models and stereotypes are established as something natural.

As the students are at the end of undergraduate program and have experienced several situations during the process, Fernández (1998) states that

(...) previous experiences with similar institutions of the same type or even with the same institution in other vital moments determine the existence of a set of meanings that shape the synthesis of the subject's past and the schema with which he or she tries to give meaning to the present (p. 22).

The above quotation corroborates that, in the space of contradictions sheltered by higher education institutions, previous experiences constitute a basic element to determine what becomes significant in interpersonal and professional relationships that are established in this space. So that in order to bring the professors' characteristics and the representations of teaching practice assessed by the students, besides the questionnaire, students' testimonies were taken at the three studied colleges: Law, Civil Engineering, and Medicine.

A significant number of students in the final years of university education, after the explanation of the reasons of the questionnaire application, volunteered to participate. The number of respondents added up to 393 students. Table 1 shows the distribution of students according to institution and college.

By presenting the data above in infographic it is possible to visualize the characteristic population of each college and each one of the participant institutions. Figure 1 provides visual perspective to this observed participation.

The largest number of student respondents were from the College of Law, followed by the College of Medicine and, in a lesser number, from the College of Civil Engineering, which presents the difference between the number of enrolled students in each college as historically verified and confirmed by INEP (Anísio Teixeira National Institute of Educational Studies and Researches) in recent assessments. 
Teaching Practice Representations: Reasons of Students' Choices

One of the questions proposed to the students aimed to identify which were the characteristics and Reasons for choosing the professor that was named as a reference in teaching practice during the undergraduate studies. Pointed out as motivators of the students' choices, the answers to the question, although inseparable of pedagogical practice, were analyzed so that it was possible to group them in four categories: content domain/knowledge, didactics/ teaching methodology, professor's personal attitudes and qualities, student's individual interest. In Table 2, it is possible to verify the number of students and the percentages of each one of these categories.

As the questionnaire was elaborated with open questions, the students were able to freely express themselves about the reasons why they have chosen a professor as a reference. Because of this in Table 2-Reasons for choosing the professor the sum of the

Table 1. Students by college and higher education institution

\begin{tabular}{ccccc}
\hline COLLEGE & UNESC & UNISUL & UNIVALI & TOTAL \\
\hline Law & 75 & 37 & 102 & $\mathbf{2 1 4}$ \\
Civil Engineering & 23 & 20 & 10 & $\mathbf{5 3}$ \\
Medicine & 34 & 49 & 43 & $\mathbf{1 2 6}$ \\
TOTAL & 132 & 106 & $\mathbf{1 5 5}$ & $\mathbf{3 9 3}$ \\
\hline
\end{tabular}

Source: Volpato's Doctoral Dissertation (2007)6.

Table 2. Categories: reasons for choosing the professor.

\begin{tabular}{ccc}
\hline Choice reason & Respondents/total of students & $\%$ of the total \\
\hline Didactics/teaching methodology & $228 / 393$ & $58 \%$ \\
Professor's personal attitudes and qualities & $220 / 393$ & $56 \%$ \\
Content domain/knowledge & $200 / 393$ & $51 \%$ \\
Student's personal interest & $\mathbf{8 2 / 3 9 3}$ & $\mathbf{2 1 \%}$ \\
\hline
\end{tabular}

Source: Volpato's Doctoral Dissertation (2007).

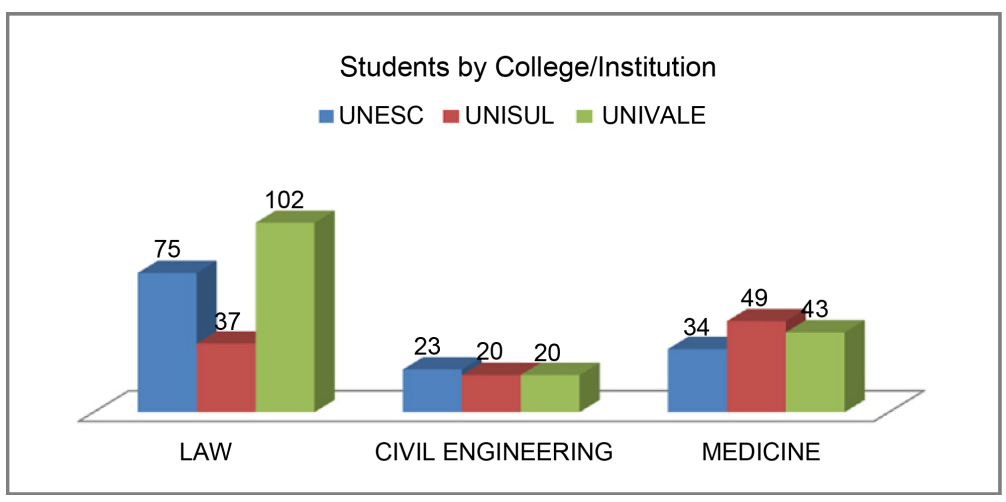

Figure 1. Distribution of student respondents by college and institution.

${ }^{6}$ For further explanations check VOLPATO, Gildo. Professionals or Professors Understanding ways, representation and assessment of teaching practice in higher education. Doctoral Dissertation, São Leopoldo: UNISINOS, 2007. 
number of students by category does not correspond to the total number of respondents. Now we will discuss each one of the categories.

\section{1) Didactics/teaching methodology}

As demonstrated in Table 2, a total of 58\% of the students presented items related to didactics and teaching methodology as reasons for choosing the professor that is their reference in teaching practice. It is important to emphasize that these categories were elaborated based on the systematization of open questions. In terms of the category of didactics/teaching methodology, we understand it as those references that pointed out the professor's good didactic skills, the relationship between theory and practice in the classroom, the use of teaching tools and techniques, finally the items that characterize a good practice, so that it was possible to establish what actions professors made clear in the classroom, according to the students' perception. The hypothesis was that all these items would make up an important representation that contributed for the choices of the professors seen as a reference.

When the answers were systematized it was verified that the students used several expressions and among them we can mention: i) clearly explains ideas and the content of the course; ii) prepares interesting and elucidative theoretical classes; iii) knows how to explain contents in a serious and, at the same time, entertaining way; iv) prepares dynamic and clearly understandable classes; $\mathbf{v}$ ) frequently makes comparisons and gives examples of real cases, making a relationship between theory and practice; vi) interacts, demands participation, discusses and debates clearing doubts; vii) is worried about classes that are related to the professionals' daily experiences; viii) relates and involves other areas of knowledge; $\mathbf{i x}$ ) tries to innovate; $\mathbf{x}$ ) explanations engage critical analysis; xi) uses time well in the classroom; xii) does not provide ready-made responses, makes students think, stimulates reasoning. This variety of statements demonstrates the coverage of didactic and methodological aspects valued by the students. Next we discuss some of the cited statements and during the analytical presentation, as long as it is possible, we try to correlate them to the representations under study.

In the three focal groups it was evident that there is convergence in the understanding that a professor with good didactic skills is the one that relates theory and practice.

"He tries to link a case report with theory, for me this is very valuable, with a clinic case explain the theory". (College of Medicine student)

"There are good didactic skills when the professor can present what he or she is explaining theoretically through practical cases. It is the type of professor and of class that raises interest". (College of Law student)

The relationship between theory and practice is perceived by the students as the professor's ability to bring concrete facts of the professional area to be considered and analyzed in the classroom. Therefore, this indicates that the professors that work in the professional area have better conditions to present and socialize the contents of the course because they are able to concretely make relations based on their experiences, making them easier to be understood. 
"His profession is the same of the course he teaches in class. He has professional experience. The practice is very important to present the details because if the professor does not have the practice experience he is unable to communicate. We do not learn only in theory". (College of Civil Engineering student)

"The first thing needed to have good didactic skills is that the professor knows what he or she is talking about, not only in theory, but also in practice. To be good at the professional life and good at theory is the first step to good didactic skills, to be able to teach". (College of Medicine student)

"The professors that have good didactic skills are those that teach a course that matches their practice experience. There are cases in which the professor teaches what he or she does not know in practice. This makes learning difficult, ends up creating uncertainty, and the classes are no longer interesting". (College of Law student)

The way they interpret, organize and convey the contents of the courses, connected with the experience of the professional area seems to be the mark of the professors that attract the students. So professors that continue working as professionals in their areas and that demonstrate consistency between what they say and what they do outside the university tend to be pointed out as a reference in teaching practice by the students who are in the final years of the undergraduate program. Once they are worried about knowing what to do and how to behave in the professional area they will soon face. So it is possible to perceive that the students do not value professors with teaching skills derived from their practice as a researchers. Why is it this way? Which are the paths the institutions should follow so that it is possible to advance in this issue? This is important in order to get closer to what Masetto (1998) states when he observes that teaching practice should demand specific competences derived not only from experience, but also from the training and education, in other words, all this is needed besides other competences.

Moreover the students have revealed an acceptance of the lecture method. For them it seems that there is no problem if the class is predominantly lecture-based provided that the professor establishes relationships between theory and practice, and involves and helps them to significantly understand the content taught. Below there are examples of their statements:

"He manages to involve the group in theoretical classes. He conveys the theory, but manages to involve us so that we understand". (College of Civil Engineering student)

"During his classes we remained in the room until the end because it was interesting, aroused our curiosity. Although they were mainly lecture-based classes, the way of teaching, held our attention". (College of Law student)

Freire (Freire \& Shor, 1987) has taught that the lecture method is not necessarily traditional; it is not in itself just transmission of contents. The teachers must have the abil- 
ity to make a class interesting and their words and testimonies must be so fascinating that the students participate with their eyes, with their entire body, attentive as they were listening to a beautiful song. For Freire (1996: p. 96),

(...) the good teacher is the one that manages, while he or she talks, to draw the student into the intimacy of the movement of his or her thoughts. The class then becomes a challenge and not a "lullaby". The students get tired, but they do not fall asleep. They get tired because they accompany the comings and goings of the teacher's thought, open their eyes in wonder at his or her pauses, doubts, uncertainties.

It is fundamental, as the author states, that teachers and students know that their posture is dialogical, open, curious, inquiring and non-passive while speaking or while listening. Before any attempt to discuss techniques, subjects, methods for a dynamic class it is necessary that the teacher knows how to raise curiosity in such a way that it becomes the trigger for the construction of knowledge. "This is what makes me question, know, act, ask again, recognize” (Freire, 1996: p. 96).

Some issues in terms of time organization and more participative ways of developing classes were presented as elements that make up a friendly scenario for the teaching practice:

"With him we give classes, look for problems and bring them to the classroom. We look for flaws, discuss and then he wants to know why it happened and what is needed to repair it. He makes us think, sees if we can solve, after that he gives his opinion". (College of Civil Engineering student)

"The professor knew how to allocate the time so that he ensured the students' communication. He did not keep talking, he assured that we also handled, worked the content". (College of Law student)

"He did not allow anyone to 'wander' in class. He kept questioning - 'And you, what do you think about this?' He made the whole group participate, not only those who speak a lot, but the shyest. To be clear or not depends a lot on the professor's way of being, regardless the subject matter itself'. (College of Law student)

The ability to communicate, express themselves, explain clearly, and the possibility of students' direct participation in the classes, added to the capacity to relate theory and practice have revealed to be important characteristics of teaching effectiveness.

The students present themselves as participants of the training process and subjectively incorporate what they experience in the classroom. This way, besides expressing their opinions about a "good" professor and reference teaching, as Urtiaga (2004: p. 102) mentions, "they externalize their ways of understanding the professionalization process that awaits them".

\section{2) Professor's personal attitudes and qualities}

The indication of $56 \%$ of the students based on the professor's personal attitudes and qualities demonstrates how much affective, emotional and ethical dimensions are va- 
lued by the students. They are human transverse dimensions, as they run through methodological issues and content domain, but have a strong influence when the students assess a professor as a reference in teaching. There are many expressions used, some give a higher value to interpersonal relationships and others to attitudes. The following stand out: i) dynamic, ii) enthusiastic, iii) good humored, iv) cheerful, v) encourages questions, vi) available, vii) dedicated, viii) interested, ix) preoccupied with learning and training, $\mathbf{x}$ ) affectionate, $\mathbf{x i}$ ) respectful, xii ethical,) xiii) patient, xiv) responsible, xv) sharing, xvi) enjoys teaching, xvii) attentive, xviii) impartial, xix) organized, $\mathbf{x x}$ ) wise, xxi) straightforward, xxii) is never absent never lacks, xxiii) charismatic, xxiv) coherent, $\mathbf{x x v}$ ) is not ironic, xxvi) does not humiliate, $\mathbf{x x v i i )}$ does not remain distant as professors usually do, xxviii) good character, xxix) places him or herself at the same level of the students, $\mathbf{x x x}$ ) dear, $\mathbf{x x x i}$ ) intelligent, $\mathbf{x x x i i )}$ ) serious, $\mathbf{x x x i i i ) ~ s t r i c t , ~ x x x i v ) ~}$ demanding, $\mathbf{x x x v}$ ) professional, $\mathbf{x x x v i )}$ sense of justice, $\mathbf{x x x v i i )}$ accurate evaluation, xxxviii) communicative, $\mathbf{x x x i x )}$ critical, $\mathbf{x l}$ ) authentic, $\mathbf{x l i}$ ) sensitive. Next we will analyze some of these concepts based on the students' testimonies.

Studies like Urtiaga's (2004) and Cunha's (1992) have identified that personal attitudes, mainly the ones related to affection, pervade the aspects pointed out by the students regarding a professor that is considered influent and outstanding. Urtiaga (2004: p. 103) researched the criteria that lead students to invite a professor to be honored during graduation ceremony and discovered that "estes critérios incluíram, principalmente, a disponibilidade, o afeto, permitir aproximação, valorizar o aluno enquanto pessoa e ensinar a pensar (these criteria mainly included availability, affection, allowing a close relationship, valuing the student as a person, and teaching how to think)".

The same way Cunha (1992: p. 69), in her studies, evidenced that

(...) it would be difficult for students to point out a professor as a good professor, or the best of the college, if he or she did not have the basic conditions in terms of knowledge of the subject or ability to organize classes, besides maintaining positive relationships. However when the students talk about the reasons of choosing a professor they emphasize emotional aspects.

Outstanding professors, according to the students, are not only the ones that challenge themselves to make the content of their course significant, but the ones that also try to establish a relation "with social, political, economic and cultural problems that characterize the current moment" in a participative and dialogic way, overturning the image of the professor as the "absolute holder of knowledge", as Balzan (2003: p. 47) stressed.

Students also value the professors' attitudes that demonstrate commitment to and involvement with teaching practice.

"He may be tired, may be dead tired, but he gets here in the classroom and renews himself". (College of Engineering student)

"There are professors that come because of the love for the profession, because they want. There is no schedule: they give classes in the evening, on Saturdays". 
(College of Medicine student)

“They must be here because they love their profession". (College of Law student)

Generally characteristics related to the professors' personal attitudes and qualities that are valued by the students are identical in the three colleges, however there are small differences due to specificities of each one of them.

In the College of Law “oratory and rhetoric" are pointed out as professors' qualities admired by the students probably because it is a very valuable resource in the professional area of the program.

In the College of Civil Engineering the students presented a smaller number of characteristics; however they have also presented the ones of the other colleges. The quality they added was that the professor should "be objective and maintain the control" maybe restating a specificity of the Engineering area.

In the College of Medicine, as a value judgment, besides the ones also mentioned in the other colleges, it was pointed out "love and dedication to patients". Students and professors of the Colleges of Medicine have a contact with patients since the very beginning of the program, in first aid service, until the end, in internship.

The punctual results of "oratory and rhetoric" in the College of Law, "be objective and maintain the control" in the College of Civil Engineering, and, finally, "love and dedication to patients" corroborate what has been stated by Cunha and Leite (1996) about values and that in each knowledge area they can be different, because indeed they depend on the history of each field, on commitments and practices of each group. These results confirm these specificities due to the obtained responses.

All the students reassured, in the focal groups, the value of professors' attitudes and procedures that build, as a consequence, a good relationship among them. Let's see some of the testimonies that testify this statement:

"Due to the respect and attention he gives to the student. He gets closer, talks. When we need him, he always meets us, as long as it is possible". (College of Law student)

"He masters the subject, is strict, but has a good relationship with his students". (College of Medicine student)

"What I think is fundamental about him is simplicity. Many people that have a major in Engineering suddenly become arrogant; they leave aside the simple way of dealing with people. In fact, it is not a question of leaving aside the simple way; it is a question of having respect for the other". (College of Engineering student)

The research confirms the findings of Cunha (1998: p. 69), in which "the reasons given by the students for choosing a good professor are directed to issues of professorstudent relationship". It seems that professors that have this characteristic will represent in the students' life not only a professional model, but that one of a human being. Moreover this profile, whose representations in some way leave a mark in the students' lives, starts to influence these students' future choices and decisions as the 
professor's way of behaving and being in the classroom seems to be related to development and identity, to specificities of the professional area. In between the lines the testimonies reveal this possibility:

"He is accessible. He is a professor that we have learned to admire precisely for the way he teaches the subject, the way he gives classes. Admiration starts in the classroom and, possibly, it spreads outwards, one as a consequence of the other". (College of Law student)

"He manages to make his students like the subject he teaches even if it is a field I am not going to follow. I have always said that I am not going to graduate in Engineering to construct, but he succeeded in making me pay attention, transmitting the knowledge. He managed to make me like it. He used to say: - Even if you are not going to follow this line of work, it is important for you to know. His subject nobody is going to forget". (College of Engineering student)

If the professor's relation and attitude can interfere positively in the choices and identification with certain future specificities of the professional area, he or she can also provoke detachment, rejection to certain specificities, depending on the way the professor deals with knowledge and relates with the students.

"This is clearly visible in the moment you choose your profession, follow your specialization". (College of Medicine student)

"When you have a professor that is rude to you, that doesn't know how to teach, and that is unwillingly here, Cardiology classes, for example, I hated, because that professor did not transmit anything, did not offer anything, you end up hating the subject". (College of Medicine student)

According to Urtiaga (2004: p. 112) the most common criticism to medical teaching "refer to the fact that professor's pedagogical actions did not get the needed attention and that usually professors are hired notably for their professional competence as physicians rather than for their preparation for teaching". One of the students of Medicine stated in the focal group that she has chosen a particular professor "because he is a professor that is a physician and not a physician that is also a professor".

When the students explained the reasons of choosing a professor based on content domain and knowledge, they were objective. Besides mentioning content or knowledge domain, they have used expressions that could be interpreted as such: clears doubts without hesitation, has updated knowledge in the area, masters knowledge, and knows a lot based on the examples he or she gives. These elements have established the category of Content domain/knowledge. Let's see them.

\section{3) Content domain/knowledge}

More than half of the students, that is, $51 \%$ has recorded in the questionnaire "knowledge domain" as an item motivating the choice of the professor as a reference in the college. This does not mean that the other students do not consider this item. However it seems that it has little value for the students if the "content domain/knowledge" is li- 
mited to the content of the professor's course, if it is not related to the didactic skill of working it in the classroom, or even if this knowledge is produced by the professor as a researcher.

"There are professors that have knowledge domain, but do not have didactic training. They know a lot, however they do not hold the students' attention, the class becomes boring. They do not know how to convey the theory, so they fumble". (College of Engineering student)

Another student of the College of Engineering contrasts stating that “(...) the professor that masters knowledge and didactics can already convey what happens in the real world. Relates the theory he is explaining so that he holds the attention". (College of Civil Engineering student)

The students value professors that know the theory of the courses they teach and that can articulate coherently what they experience as professionals. In the students' opinion, this is demonstrated through the answers given to questionings made in the classroom.

"The professor must be confident to reply the questions and have the ability to relate the content to other courses. The professor I chose does this, he answers and does not escape into idle talk. When the professor does so it is because he does not know the answer". (College of Law student)

"First because he demonstrates self-confidence, because he knows the content and answers questions about several medical issues. He explains properly, does not escape into idle talk. If there is something he does not know, he says he is going to research or tells where you can research. I have chosen him mainly because of his confidence in answering". (College of Medicine student)

Alarcão (1998: p. 104) states that "teacher's knowledge neither is merely academic, rational, made of facts, notions or theories, nor is a knowledge only made up of experience. (...) It is to know how to act in different situations". It seems the students expect that professors are always ready to act and answer the questionings and that they have full knowledge of the content of their answers. Maybe due to this they value the ones that have this profile. After all the individual has a connection between personal and professional dimensions that are, according to Castanho (2003: p. 57), "inextricably linked".

The choice of the professor as a reference has also occurred due to the student's personal interest in the subject when the course content corresponded to satisfaction of immediate needs or future expectations, as discussed in the next item.

\section{4) Student's personal interest}

A percentage of $21 \%$ of the students seem to signal that not only didactics, knowledge domain in the area, professor's personal attitudes and characteristics determine the choice for the reference in teaching. They associate the choice to their personal and previous interests by stating: i) it is an area I identify myself with and I wish to follow; 
ii) has met my expectations; iii) for me it was the best course; iv) it was the course that helped me most during internship; v) due to the information and knowledge I received; vi) called my attention and I have learned the most; vii) presented didactic training and knowledge domain that matched my way of being; viii) it was the course that was more connected to my professional activity; ix) I have used the contents and knowledge of this course in my daily life; $\mathbf{x}$ ) the course presented what I desired; $\mathbf{x i}$ ) opened my mind to the questionings I had; xii) has to do with the way I see things; xiii) due to the interest in an inheritance, because at the end I was able to develop structural projects alone.

This testimonies show that teaching and learning are always connected and that the students' motivations are essential in their perception of teaching. When professionals can count on the students' positivity they have better chances of attaining their goals.

\subsection{Synthetic Overview of Other Correlations}

The differences present in the students' reasons for choosing a professor were not significant between colleges. Figure 2 presents the results with indicators that correspond to each category in the universe of the three universities researched.

Although there is a small margin of difference, it seems that the professor's "content domain/knowledge" is more important for the students of the College of Civil Engineering $(52.83 \%)$, followed by the students of Law $(51.86 \%)$, and then by the students of Medicine (48.41\%).

The colleges in which the students took more account of "didactics/teaching methodology" were Law (62.61\%), then Civil Engineering (58.49\%). On the other hand the students of the College of Medicine valued most the professor's "personal attitudes and qualities" (61.90\%).

Personal interest for the course content as the reason for choosing the professor as a reference had the highest number among the students of the College of Law (25.70\%),

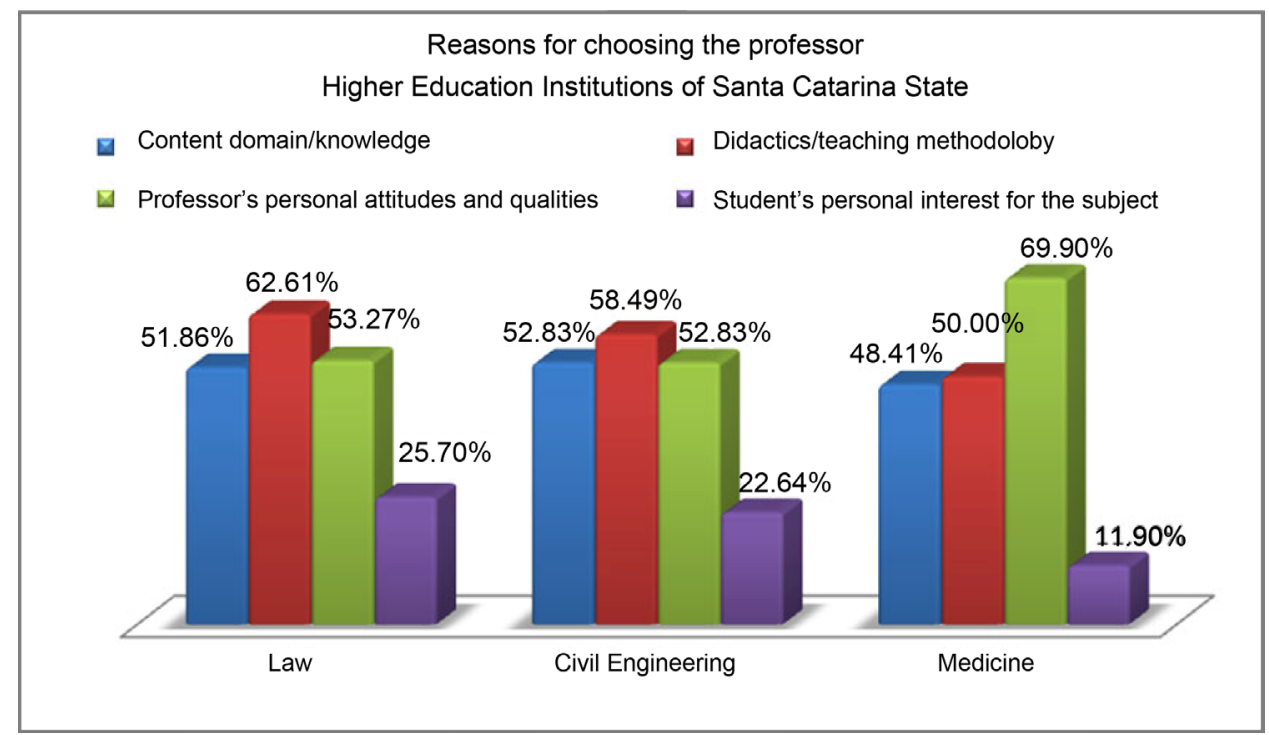

Figure 2. Distribution of the choices in categories of respondents from ACAFE. 
followed by Civil Engineering (22.64\%), and, finally by the College of Medicine (11.90\%).

Personal interest is less important for the students of the College of Medicine, a possible reason for this can rest on the fact that they study full-time, and so they cannot work or have paid internships as the other students. Maybe, due to this, personal interest has less influence once they do not have immediate needs to be satisfied for their work.

Volpato, during the doctoral internship in Argentina, from September 3, 2006 to March 3, 2007, applied a similar questionnaire to the students at the final years of the same colleges at the Universidad de Buenos Aires (UBA (University of Buenos Ayres)) ${ }^{7}$.

It is important to stand out that the insertion did not intend a comparative study. Volpato only tried to know how the students of another country, another culture, other habits and values viewed the issues raised in the study with the students in the final years of the three universities of Santa Catarina State in Brazil. Even with the focus on the understanding local or regional reality, the researcher intended, besides analyzing the theories, to collate with the empirical data of the Argentine students. The purpose was to understand some field issues that extrapolate the local experiences and representations.

The issues that point out professors that receive good evaluations so that they become a reference are basically the same. The percentages are very similar among the colleges.

In this case the students of the College of Law have also presented reasons related to professors' critical and political view in the course they taught. The students of the College of Medicine have reinforced that the professors' personal behavior and attitudes are characteristics most valued by them. These are expressions that refer to categories as presented in Figure 3.

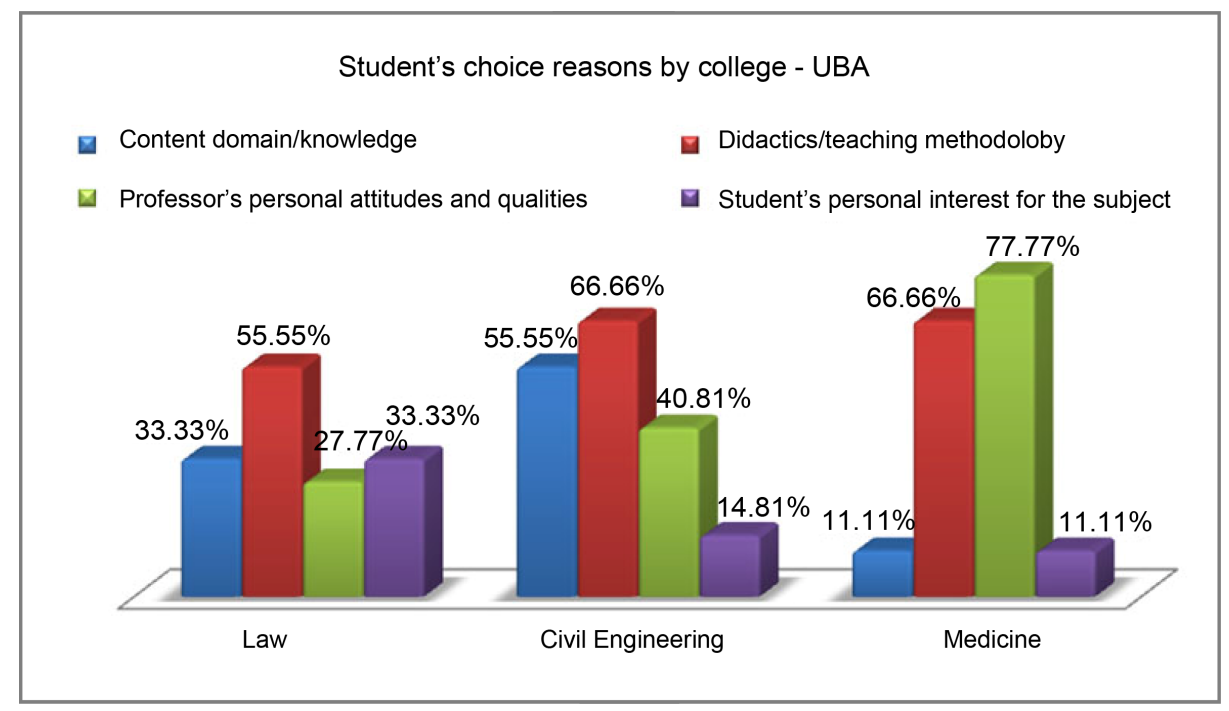

Figure 3. Distribution of choices in categories of respondents from UBA.

${ }^{7}$ The researcher had the aid of Professor Elisa Lucarelli, researcher and professor at UBA, that opened doors and enabled the contacts with the three colleges: Law, Civil Engineering and Medicine. The questionnaire was applied at the College of Law in October, and Colleges of Medicine and Engineering in November 2006. 
Urtiaga (2004), in a study about students' culture, demonstrated that the positive image of the professor, created by the students, is mediated by representations that result from internal constructions of meanings according to the students' cultural background. So the students identify their own values interacting with professors' values revealed during classes. Pérez Gomes (2001) states that the students' culture is a an expression of their communities and these are always mediated by their biographical experience closely linked to the context.

Cunha (1989: p. 67) in her doctoral dissertation has also identified that

the student's choice of a GOOD PROFESSOR is permeated by his or her social practice, that is, the result of the appropriation of practice and social and historical knowledge. Appropriation is a reciprocal action between individuals and different spheres or social integrations. However they are different in individuals, that is, they make appropriations in a different way due to their interests, values, beliefs, experiences and so on. This is demonstrated by the differentiation that exists between the students' behavior when they propose the GOOD PROFESSOR.

It is necessary to emphasize that the students' perspective also presents a strong cultural background. It is the result of a conception of knowledge and school practices with a strong tradition on the modern presuppositions. Under this perspective the professor has always been seen as the defining element of pedagogical practices and the student has been seen as a receiver. This perception leads to a conception of teaching practice that holds liable the professor. The representations involved seem not to include the relationship teacher-student as an interaction process whose result is the production of knowledge.

\section{Conclusions}

The professors are chosen by the students as a reference in teaching practice because they have achieved prominence in their practice and empowered themselves both as professionals and as professors, although we advocate that these representations distance themselves from what is desirable for higher education, that is, teaching-as-research.

Among the expectations the students have of their professors, according to their representations of good teaching practice, we highlight:

- Master the subject and demonstrate this even with "lectures", making the needed mediations and furthering the knowledge in the case of students' presentations of case studies, seminars and so on.

- Know how to establish relations between theory and the daily professional practice. As the professor has worked or still works in the profession, bring cases to be solved or exercises to be developed in the classroom.

- Respect the students by being accessible and attentive.

- Demand and require that which has been taught and be present during the class.

- Enjoy giving classes and demonstrate this with attitudes. 
- Worry about the consistency between what is presented during classes and what is required in assessments.

Beyond the professor's knowledge domain, methodology and personal attitudes, students also choose professors due to personal interests, motivations and needs. This indicates that it is not always the professor's performance that weighs on the assessment on the whole in terms of the representation that constitutes a positive marker well evaluated.

The internship in Argentina supported the collation with theoretical studies and research results about university teaching practice accomplished in that country. It has also provided the condition to support the idea that many of the characteristics and attitudes valued in professionals' teaching practice as well as the small differences between the colleges, which result from the object to which the education is destined, extrapolate local or regional dimensions and can only be understood in the structure of the professional area. Due to this, the students in the final years of the program of UBA have also pointed out as a teaching reference of the professors that taught courses of the major area of the professional education and that, in most cases, also work in the professional area.

The view of good professor revealed by the students constitutes a fundamental indicator for the educational processes. However, it is also necessary to have a critical view about it in order to advance towards new epistemological references. The rupture with traditional models is desirable for professors as well as for students. Moreover the research can be an important tool to reach this, mainly to add value to qualification in several areas of knowledge.

To know about the conditions and be aware of social constraints that produce many difficulties is important and maybe, it can empower higher education professionals: power to resist, to move in the opposite direction, because it is amid contradictions that professors can resist the structures and try to develop other practices, other logics, other rationalities in the university, producing another culture of action and teaching practice assessment.

\section{References}

Alarcão, I. (1998). Continued Formation as an Instrument of Professors Professionalization. In I. P. A. Veiga (Org.), The Ways of the Professional of Magistery (3rd ed., pp. 99-122). Campinas: Papirus.

Antonio Cunha, L. (1998). University Reform in Crisis: Administration, Structure and Territory. Avaliation Journal, 3, 7-21.

Balzan, N. C. (2003). Excelency Level Universitary Teaching, Limits and Possibilities in Two Areas of Knowledge: Human Sciences and Applied Social Sciences. Revista de Educação PUC-Campinas, 15, 39-53.

Bernstein, B. (1990). On Pedagogic Discourse. Vol. 4: Class, Codes and Control, London: Routledge.

Bourdieu, P. (1983). The Scientific Field. In O. Renato (Org.), Sociologia (pp. 122-155). São Paulo: Ática.

Bourdieu, P. (1996). Practic Reasons: About the Thoery of Action. Translation by Corrêa, M., 
Campinas: Papirus.

Castanho, M. E. L. M. (2003). The Social Sciences Superior Teaching Professor and Its Pedagogical Practice. Revista de Educação PUC-Campinas, 15, 55-62.

Chauí, M. (2001). Writtings on University. São Paulo: Editora UNESP.

Cunha, M. I. (1989). The Good Teacher and Its Practice. Campinas: Papirus.

Cunha, M. I. (1998). The University Professor and the Paradigm Shift. Araraquara: JM Editora.

Cunha, M. I. (2004). Teaching as Complex Action: The Role of Didacticism in the Formation of Professors. In J. P. Romanowski, P. L. O. Martins, \& S. R. A. Junqueira (Orgs.), Local Knowledge and Universal Logic: Research, Didactics and Teaching Action (pp. 31-42). Curitiba: Champagnat.

Cunha, M. I., \& Leite, D. (1996). Pedagogical Decisions and Power Structures in Univesity. Campinas: Papirus.

Cury, C. R. J. (2006). Policies of Superior Education and the Pedagogic Practice: A Frame of the Legal Order and Its Repercussions. In A. Maria Monteiro Silva et al. (Eds.), Anais do ENDIPE, Encontro Nacional de Didática e Prática de Ensino (pp. 521-532). Recife.

Dias Sobrinho, J. (2005). Dilemmas of Superior Education in the Globalized World: Society of Knowledge or Economy of Knowledge? São Paulo: Casa do Psicólogo.

Enguita, M. F. (1991). The Ambiguity of Teaching: Between Professionalism and Proletarization. Theory and Education Journal, 4, 41-61.

Fernández, L. M. (1998). The Analysis of the Institutional in School: A Contribution to the Self-Managing Formation for the Usage of Intitutional Approaches. Buenos Aires-BarcelonaMéxico: Paidós.

Freire, P. (1996). Autonomy's Pedagogics: Necessary Knowledges to the Educative Practice. Rio de Janeiro: Paz e Terra.

Freire, P., \& Shor, I. (1987). Fear and Boldness: The Daily Basis of the Professor (5th ed.). Rio de Janeiro: Paz e Terra.

Guidi, M. L. (2001). Images of a Pratice of Physical Education Professors: A Perspective on the Representations of the Professors in This Specialty. Masters in Education Dissertation, Faculdad de Filosofía y Letras, UBA.

Kessler, M. C. (2002). Problematizing the Production of Eclusion by Knowledge: The Case of Mathematics. Doctoral Thesis, São Leopoldo: Programa de Pós Graduação em Educação, UNISINOS.

Masetto, M. (Org.) (1998). Teaching in University. Campinas: Papirus.

Nóvoa, A. (1992). Professors and Their Lifestories. In A. Nóvoa (Org.), Professors Lives (pp. 11-30). Portugal: Porto Editora.

Sousa Santos, B. (1999). By Alice's Hand: The Social and The Political in Postmodernity (2nd ed.). São Paulo: Cortez.

Tardif, M. (2000). Professional Knowledges of Professors and Scholastic Knowledge. Elements for an Epistemology of the Professor's Professional Practice and the Consequences to Mastership Formation. Brazilian Journal of Education, 13, 5-24.

Tardif, M. (2002). Teaching Knowledge and Professional Formation. Petrópolis: Vozes.

Urtiaga, M. E. O. (2004). The Mediation of the Teaching Culture in Medical Formation. Pelotas: Editora e Gráfica Universitária-UFPel.

Volpato, G. (2007). Professionals or Professors Undestanding Ways, Representation and Assessment of Teaching Practice in Highter Education. São Leopoldo: Doctoral Dissertation, UNISINOS. 


\section{Appendix A}

OPEN QUESTIONS QUESTIONNAIRE, APPLIED TO LAW, CIVIL ENGINEERING AND MEDICINE STUDENTS

Questions:

1) Who is the best professor in your undergraduate course?

2) Why do you consider him/her better than other professors? How?

3) What course did you have more significant learning?

Why do you think it was more significant?

\section{Appendix B}

\begin{tabular}{|c|c|c|c|c|}
\hline $\begin{array}{l}\text { Higher Education } \\
\text { Institutions }\end{array}$ & \multicolumn{2}{|c|}{ Data of Higher Education Institutions } & \multicolumn{2}{|c|}{$\begin{array}{l}\text { Colleges - focus } \\
\text { of the study }\end{array}$} \\
\hline \multirow{3}{*}{$\begin{array}{l}0 \\
\text { บ } \\
\text { 号 }\end{array}$} & Colleges & 36 Undergraduate colleges & Engineering & $\begin{array}{l}393 \text { students } \\
41 \text { professors }\end{array}$ \\
\hline & Students & 11,000 students enrolled & Law & $\begin{array}{l}1160 \text { students } \\
60 \text { professors }\end{array}$ \\
\hline & Professors & $\begin{array}{c}700 \text { (of which } 254 \text { masters } \\
\text { and } 60 \text { doctors) }\end{array}$ & Medicine & $\begin{array}{l}355 \text { students } \\
124 \text { professors }\end{array}$ \\
\hline \multirow{3}{*}{ 宫 } & Colleges & $\begin{array}{l}56 \text { undergraduate colleges } \\
\text { and sequential programs }\end{array}$ & Engineering & $\begin{array}{l}350 \text { students } \\
38 \text { professors }\end{array}$ \\
\hline & Students & 25,000 students enrolled & Law & $\begin{array}{l}1187 \text { students } \\
57 \text { professors }\end{array}$ \\
\hline & Professors & $\begin{array}{l}1507 \text { (of which } 541 \text { masters } \\
\text { and } 215 \text { doctors) }\end{array}$ & Medicine & $\begin{array}{l}493 \text { students } \\
144 \text { professors }\end{array}$ \\
\hline \multirow{3}{*}{ 学 } & Colleges & $\begin{array}{l}59 \text { undergraduate colleges } \\
\text { and sequential programs }\end{array}$ & Engineering & $\begin{array}{l}250 \text { students } \\
33 \text { professors }\end{array}$ \\
\hline & Students & 30,850 students enrolled & Law & $\begin{array}{l}1740 \text { students } \\
99 \text { professors }\end{array}$ \\
\hline & Professors & $\begin{array}{c}1623 \text { (of which } 853 \text { masters } \\
\text { and } 249 \text { doctors) }\end{array}$ & Medicine & $\begin{array}{l}399 \text { students } \\
103 \text { professors }\end{array}$ \\
\hline
\end{tabular}


Submit or recommend next manuscript to SCIRP and we will provide best service for you:

Accepting pre-submission inquiries through Email, Facebook, LinkedIn, Twitter, etc. A wide selection of journals (inclusive of 9 subjects, more than 200 journals)

Providing 24-hour high-quality service

User-friendly online submission system

Fair and swift peer-review system

Efficient typesetting and proofreading procedure

Display of the result of downloads and visits, as well as the number of cited articles

Maximum dissemination of your research work

Submit your manuscript at: http://papersubmission.scirp.org/

Or contact ce@scirp.org 